AperTO - Archivio Istituzionale Open Access dell'Università di Torino

\title{
Institutional Logics Analysis for Enabling Collaborative DPM Processes: Universities' Third Mission Performance as an Illustrative Example
}

\section{This is the author's manuscript}

Original Citation:

\section{Availability:}

This version is available http://hdl.handle.net/2318/1766729

since 2021-01-14T00:59:46Z

Publisher:

Springer International Publishing

Published version:

DOI:10.1007/978-3-030-42970-6_13

Terms of use:

Open Access

Anyone can freely access the full text of works made available as "Open Access". Works made available under a Creative Commons license can be used according to the terms and conditions of said license. Use of all other works requires consent of the right holder (author or publisher) if not exempted from copyright protection by the applicable law. 


\title{
Institutional logics analysis for enabling collaborative DPM processes:
}

\section{Universities' third mission performance as an illustrative example}

\author{
Francesca Ricciardi $^{1,},{ }^{*}$, Paola De Bernardi ${ }^{1}$, Canio Forliano ${ }^{1,2}$, Mattia Franco $^{1}$ \\ ${ }^{1}$ Department of Management, University of Turin, C.so Unione Sovietica 218/bis, 10134, Turin; \\ francesca.ricciardi@unito.it; paola.debernardi@unito.it; mattia.franco@unito.it \\ ${ }^{2}$ Department of Political Science and International Relations, University of Palermo, 90134 Palermo, \\ Italy; canio.forliano@unito.it \\ *corresponding author
}

\begin{abstract}
The literature increasingly encourages public managers and policymakers to develop recursive cycles of collective and collaborative mental model formalisation for improved organisational learning, reporting, and decision-making. Dynamic Performance Management (DPM) is a promising approach to address this challenge. However, the actors involved in the system under study often display different cultures, values and social expectations, which may hinder successful collaboration around a DPM modelling process. Our study develops a process for mapping the different institutional logics that are likely to influence the DPM modelling processes in a certain context, thus creating the conditions for a more systematic, inclusive and collaborative DPM modelling process. Also, this study provides an illustrative example of the proposed institutional-logics-based approach to DPM by identifying the different public value resource stocks that are expected to result from universities' third mission.
\end{abstract}

Keywords: Dynamic Performance Management, institutional logics, system dynamics, public value, third mission, university performance 


\section{Introduction}

A performance management system is any system that generates performance information (through specific routines) for supporting reporting and decision making processes (Moynihan, 2008). Dynamic Performance Management (DPM) is a particular form of performance management system based on the system dynamics approach (Sterman, 2000). As such, DPM is an adaptive, feedback-based, outcome-based and learning-oriented approach to performance management (Borgonovi, Bianchi, \& Rivenbark, 2017). Besides, DPM enables to identify, map and operationalise feedback loops between variables, such as vicious and virtuous cycles (Sterman, 2000). The key purpose of DPM modelling is (collaborative, agile and adaptive) management, rather than prediction per se. DPM is specifically conceived to allow for collaborative, qualitative mapping and modelling, and sophisticated mathematical elaborations (although possible) are not required to use DPM. This focus on concrete management processes differentiates DPM from many other system modelling approaches, such as agent-based modelling (Macy \& Willer, 2002).

Since it has been specifically developed to tackle complexity, DPM is considered particularly suited to support decision making when the public value is at stake, like in the case of government bodies or other institutions with (possibly) significant social and environmental impact (Cosenz, 2018). In this light, DPM may target not only a specific organisation's efficiency, profitability and/or long-term survival, but also that organisation's impact on the common good (Deber \& Schwartz, 2016), as well as the impact of policies, investments, and other decisions.

DPM modelling can be conducted by experts, researchers or consultants, based on their expertise and understanding of a certain system's dynamics. However, it is becoming increasingly clear that DPM is more effective and powerful if adopted as a basis for collaborative, ever-evolving modelling on the part of a whole community of diverse stakeholders, rather than traditional top-down, onceforever expert modelling (Bianchi, 2016). DPM's main value resides in its ability to capture complexity and change, and it is substantially impossible to achieve this through a few experts' isolated efforts. It is not surprising, then, that the DPM literature increasingly encourages to leverage DPM conceptual tools to develop recursive cycles of collective and collaborative mental model formalisation and fine-tuning for improved organisational learning and decision-making (Bianchi, 2016). This is in line with the important role of adaptive and collaborative governance and adaptive co-management, that is increasingly highlighted by the public management literature (Ansell, 2011; Ansell \& Gash, 2008; Eversole, 2011).

However, this effort of recursive and collective (re)modelling is a tough challenge. If the generation of public value is at stake, the analysis of strategic resources and key performance drivers must be conducted at the system level, rather than at the single organisation's level; and actors from different organisations or interest groups must be involved (Noto \& Noto, 2018). In this situation, not only are actors sometimes influenced by interests that can be rationally identified as conflicting; in most cases, actors also display different cultures, values, and social expectations, which may hinder successful collaboration at least as heavily as the so-called rational conflicts of interest (Negoita, 2018). As a consequence, the views of the actors participating in collaborative modelling may diverge dramatically as for what should be considered a strategic resource or a key performance driver in modelling their system through DPM. In other words, the identification of the key variables, far from being a neutral or rational process, is a social game requiring innovative management tools, since the traditional management solutions are likely to be of little help in collective DPM modelling. We still know very little about how we could understand and manage the dynamics that make the social process of DPM modelling so difficult (Sorci, 2017). This is surprising since these difficulties may 
hinder DPM from expressing its full potential in supporting organisations and institutions that address wicked societal problems (Bianchi, 2015).

This study leverages the literature on institutional logics (Wooten \& Hoffman, 2008) to address this gap. The institutional logics lens is a powerful conceptual tool to identify the different clusters of internally consistent rules, roles and social expectations that shape the social fabric, and then also the system to be modelled through DPM (Luna-Reyes \& Gil-Garcia, 2011). Not surprisingly, institutional logics are at the centre of a growing stream of studies in the public management and e-government fields (Dover, 2010; Saz-Carranza \& Longo, 2012; Wahid \& Sein, 2013). This study develops a process for mapping the different institutional logics that are likely to influence the DPM modelling process in a certain context. Thanks to the identification of the relevant institutional logics and the actors holding them, the individual or team coordinating the collaborative DPM modelling process can develop specific solutions and techniques to manage the tensions between the actors participating in the process, thus creating the conditions for more effective collaboration.

In the final part of this study, we propose an illustrative case in which this institutional-logicsbased approach to the management of DPM collaborative modelling processes is adopted. In the proposed case, we address universities' third mission systems, that is, those systems through which universities co-create knowledge-based value by interacting with the external environment (the other two missions of universities consist in co-creating value with the students and the scholarly community: teaching and research, respectively) (Fuster, Padilla-Meléndez, Lockett, \& Del-ÁguilaObra, 2019; Sánchez-Barrioluengo \& Benneworth, 2019; Secundo, Elena Perez, Martinaitis, \& Leitner, 2017). This case is particularly interesting because the identification of key variables/indicators and cause-effect relationships is typically controversial in university ecosystems (De Bernardi, Azucar, Forliano, \& Bertello, 2020; Garcia-Perez-de-Lema, Madrid-Guijarro, \& Martin, 2017; Gür, Oylumlu, \& Kunday, 2017; Kapetaniou \& Lee, 2017; Mejlgaard \& Ryan, 2017; Montesinos, Carot, Martinez, \& Mora, 2008).

Through triangulated qualitative research, we find that universities' third mission systems are shaped by at least four different institutional logics, which we label as dissemination logic, engagement logic, translational logic, and entrepreneurial logic, respectively. Then, we show how these four logics influence the identification of the key strategic resources (a critical step in DPM modelling), and how a full awareness of these four logics enables a more orderly and inclusive mapping of the key DPM variables. Finally, the illustrative case suggests that thanks to this new approach to DPM variable mapping, a more constructive and creative process of collaborative DPM cause-effect relationship mapping is possible. Based on the results of this study, we argue that DPM modelling processes benefit from the active role of a focal (individual or collective) actor that takes care of understanding the different institutional logics at stake and manages the collaboration processes accordingly.

The contribution of this study is threefold. First, this study contributes to the literature on DPM by proposing a novel, institutional-logics-based approach to DPM modelling that could be particularly useful in all those cases in which the (re)generation of relevant common resources and public value is at stake (Bianchi, 2015; Bianchi, Bovaird, \& Loeffler, 2017; Borgonovi, Anessi Pessina, \& Bianchi, 2018; Borgonovi et al., 2017; Luna-Reyes \& Gil-Garcia, 2011).

Second, this study contributes to the emerging literature stream that investigates the role of institutional logics and organisational fields for the (re)generation of public value, particularly through feedback-based approaches that can become data-driven learning engines (Rossignoli, Ricciardi, \& Bonomi, 2018).

Third, this study paves the way to further specific SD- and DPM-based studies on the universities' third mission and, more generally, on the governance of universities as engines of complex systems 
of public value co-creation (Cosenz, 2014; El-Jardali, Ataya, \& Fadlallah, 2018; Raafat et al., 2013; Skribans, Lektauers, \& Merkuryev, 2013). In particular, the adoption of the proposed approach as support for sense- and decision-making both by university managers and policymakers could be viewed as a contribution to practice, on the one side, and scientific experimentation of the model's effectiveness and accuracy, on the other side.

\section{Background}

\section{DPM modelling}

DPM (Bianchi, 2015; Bianchi, Bovaird, \& Loeffler, 2017; Borgonovi, Anessi Pessina, \& Bianchi, 2018; Borgonovi et al., 2017; Luna-Reyes \& Gil-Garcia, 2011) identifies four types of key variables describing the system to be managed: stocks (i.e., key strategic resources that can be leveraged for pursuing the organization's goals and whose reduction under a critical threshold would result in system collapse: for example, customer base), flows (i.e., the rates through which resources are accumulated or depleted; flows include the organization's results, such as the number of new customers in a year), performance drivers (i.e., intermediate variables that can be usually expressed in terms of capabilities and may affect flows: for example, delivery time compared to expectations, that may affect customer flows) and input variables (i.e. those variables that can be directly affected by decision-makers and directly affect action, including both operational constraints, such as the adopted software solution, and behavioural drivers, such as policies).

The DPM modelling activities typically result in layer and arrow models like the instance depicted in Figure 1. Rectangles typically represent resource stocks; large arrows entering/exiting the rectangles depict resource flows; while performance drivers and input variables can be distinguished by using circles and diamond-shape symbols, respectively (Bianchi, 2016, p. 23). Thin arrows represent cause-effect relationships.

Figure 1. An instance of DPM modelling: a layer \& arrow model of a water utility company.

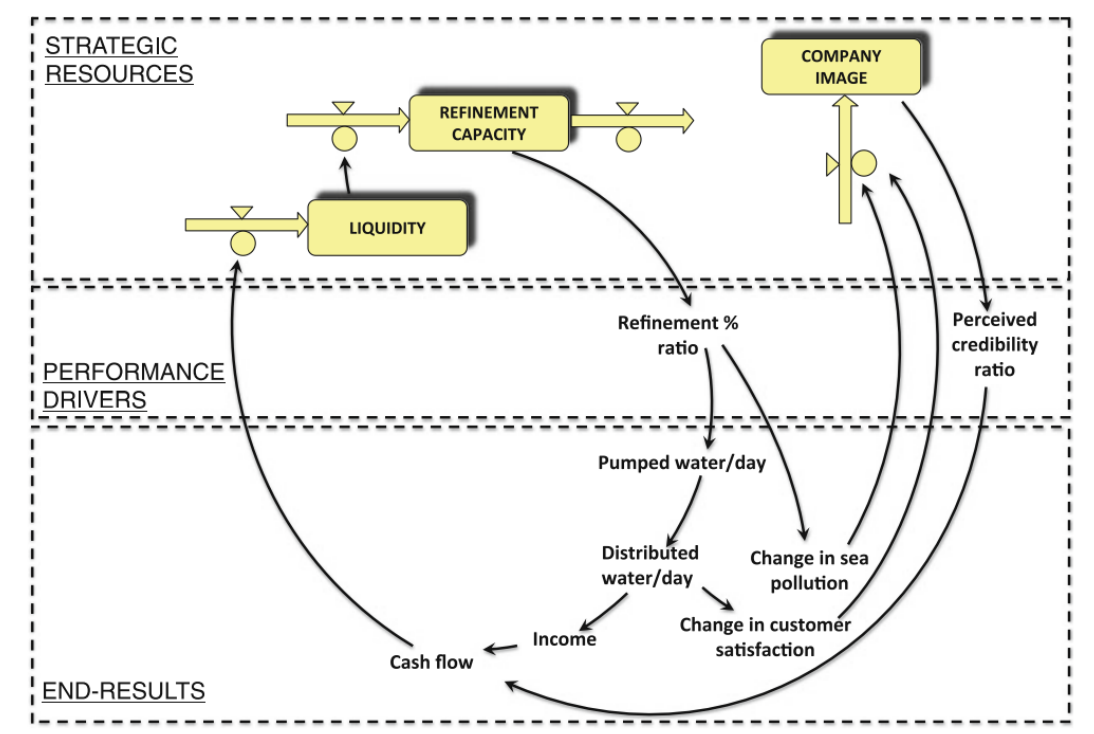

Source: Bianchi (2016). 
Interestingly, the DPM approach allows one to model the system around the key resource stocks. In many DPM models, only organisational-level resource stocks are considered, i.e., resource stocks for the exclusive benefit of the organisation under study (e.g., liquidity) and/or depending (almost) exclusively on organisational-level capabilities/performance drivers (e.g. organisation's credibility ratio). However, since there is growing attention on DPM as a tool for reporting and decision-making around the generation of public value and the common good, DPM modelling increasingly include also resource stocks for the collective or common benefit and depending on multiple actors' behaviours (such as people's employability or air quality).

Then, the first key step in developing DPM consists in identifying the strategic resource stocks, both those that are available for the organisation's exclusive benefit (such as liquidity) and those that are available for collective use, including the organisations among the beneficiaries/contributors (such as the city's mobility capacity). Once the key resources are identified, the key results can be identified among the corresponding inflows and outflows; then, the DPM modeller has the proper basis for identifying the performance drivers (that is, the key capabilities that can influence flows) and inputs (that is, the technological, infrastructural, institutional and organizational factors that can influence the performance drivers).

Therefore, the DPM modelling process implies an orderly top-down activity, in which the key management variables (that is, results, performance drivers/capabilities, and inputs/behavioural drivers) can be deduced based on the analysis of the key strategic resource stocks. On the one side, this strong focus on (private and common) resources is an important strength of the DPM approach, because it forces to restructure the measurement, organisation and management activities around resource stocks and their fragilities, thus providing the basis for organisation-level and system-level sustainability and resilience. On the other side, the DPM approach is vulnerable to poor resource stock identification: if the DPM modeller fails in identifying all of the system's key resource stocks, all the resulting mental model (including the identification of the key managerial variables, that is, performance drivers and inputs) is likely poor.

Unfortunately, the initial phase of key resource stock identification is particularly difficult. When invited to identify the key resource stocks, people are strongly influenced not only by their perceived interests, but also, and maybe even more importantly, by their beliefs, habits, and social environments. Therefore, if the identification of key resource stocks is left to few people, it will be likely incomplete; if it is entrusted to a group including numerous people with different views and social expectations, conflicts may arise that may lead to power-led decisions (the opinion of the weakest coalitions are discarded and not included in the DPM model) and/or watered-down compromise (only the variables that look acceptable to all the parties are included in the DPM model).

In other words, the very first and crucial phase of the DPM modelling process, that is, the identification of the key resource stocks needs clearer solutions for identifying who should be involved in the identification of variables and how the different ideas on key variables could be leveraged systematically and constructively.

\section{Organisational fields and institutional logics}

The vast and viable literature on institutional logics (Thornton, Ocasio, \& Lounsbury, 2012) provides conceptual tools that can be very useful for supporting the first, critical phase of the DPM modelling process, as described in the previous paragraph.

An institutional logic is a socially recognised system of rules, values, expectations and beliefs that are catalysed by and around societal institutions, such markets, universities or social movements (Sauermann \& Stephan, 2013; Wooten \& Hoffman, 2008). Institutional logics shape behaviours and make cooperation and reciprocal understanding possible. For instance, the family institutional logic 
is a societal-level system of laws, roles, expectations and assumptions prioritising the nurturing and generative capabilities of the family, along with its safety and wellbeing (Fairclough and Micelotta 2013). The family logic can be inflected in many ways: for example, a traditional patriarchal family logic is based on different assumptions and rules compared to those shaping contemporaneous cosmopolitan families of Western countries.

According to the most recent developments of institutional studies, institutional logics transform industrial sectors into organisational fields (Greenwood, Díaz, Li, \& Lorente, 2010), that is, relational spaces governed by rules, values and cognitive assumptions rather than mere market forces and abstract rational choices.

Institutional logics co-evolve dynamically through technological and scientific innovations, activism, political action, institutional entrepreneurship and bottom-up practice-driven changes (Ansari, Wijen, \& Gray, 2013; Beckert, 2010; De Bernardi, Bertello, \& Shams, 2019; Greenwood, Hinings, \& Whetten, 2014; Zietsma \& Lawrence, 2010). There is growing awareness on the role of entrepreneurs, managers and governance bodies in triggering, navigating and shaping the evolution of a certain organisational field's logics and in making this evolution sustainability-oriented (or not) (Cantino, Devalle, Cortese, Ricciardi, \& Longo, 2017).

In terms of DPM, we can have at least as many different views on the system under study as the number of different institutional logics shaping the relevant organisational field. For example, a smart city system is typically populated by several logics, such as the innovation logic and the equality logic (Pierce, Ricciardi, \& Zardini, 2017). These logics may differ significantly as for the respective views on the city system. For example, the innovation logic values technology transfer, entrepreneurial initiatives, maximising opportunities for start-ups and university spin-offs, entrepreneurial risktaking, creative destruction and innovation partnerships. Conversely, the equality logic values inclusion, participation, human rights; and fights against power, selfish business and privilege (Pierce et al., 2017).

The different logics populating a field may be reciprocally reinforcing but also conflicting (De Bernardi, Bertello, \& Forliano, 2019), and DPM may provide useful tools to map the vicious and virtuous cycles within and across different logics. Therefore, the analysis of the organisational field and particularly of the logics shaping it is extremely useful to enable multi-faceted DPM modelling that takes into account different views in a generalizable way. In this light, each institutional logic can be viewed as a high-level input variable, which results in a logic-specific set of rules, roles and social expectations. Different logics likely lead to the identification of different resource stocks as relevant and legitimate targets and of different specific performance drivers as significant, acceptable and feasible means. For example, people following the innovation logic likely identifies the number of active entrepreneurial initiatives as a key stock of a certain city, while people following the equality logic likely focus on very different resource stocks, such as the funds available for helping the poor.

\section{Managing DPM Modelling processes through Institutional Logic Mapping}

If the analysis for DPM modelling is conducted at the organizational field level, rather than at the level of the individual organization, and has the purpose of mapping the dynamics that are relevant to the common good and public value, it is almost inevitable that the key actors of the system under analysis are influenced by different, and likely conflicting, institutional logics.

Therefore, based on the theoretical background and considerations synthesised above, we propose that the management of the DPM modelling processes takes care of how different institutional logics express different views about the key resources of common interest, and consequently the relevant flows, performance drivers and inputs to be included in DPM models. 
Our proposal implies an activity of institutional logics mapping that is preliminary to the DPM modelling process and also helps identify the different key views that should be invited to participate in collaborative modelling. The proposed process of preliminary institutional logics mapping and key actor identification is synthesised in Figure 2.

Figure 2. The proposed process of institutional logic mapping is preliminary and preparatory to the DPM modelling process.

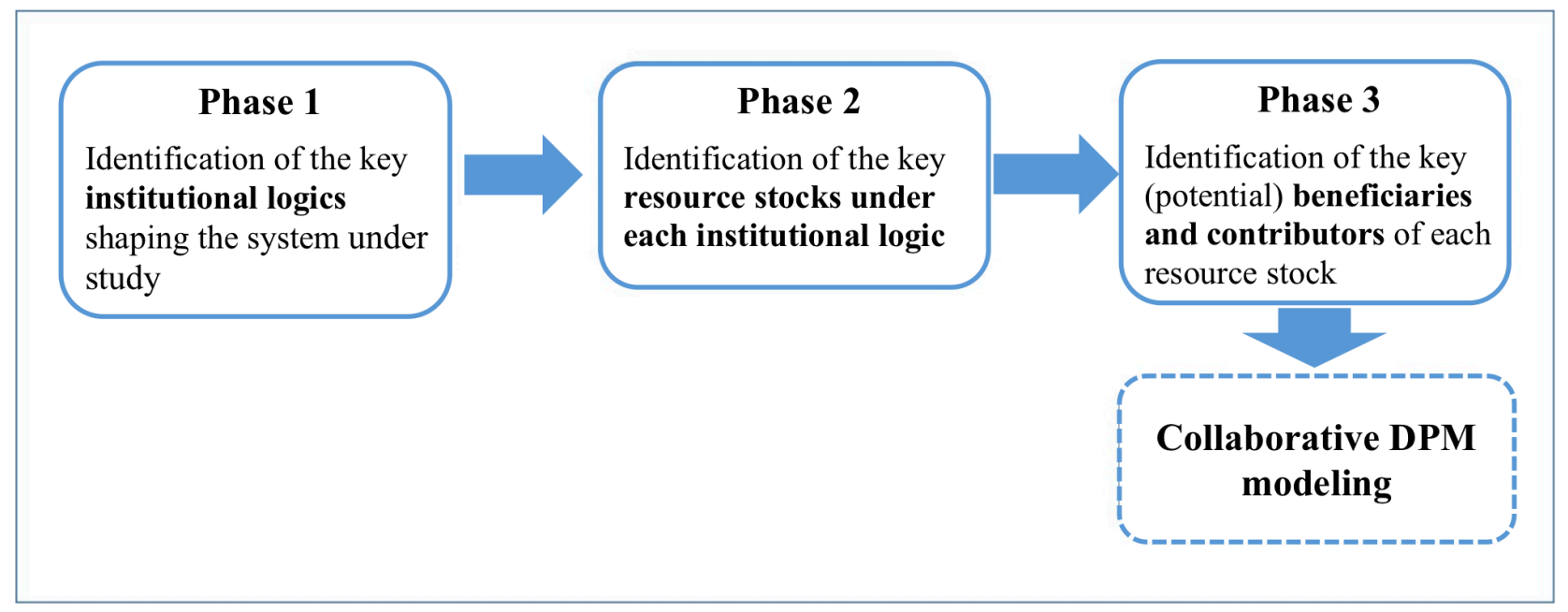

Source: authors own elaboration.

In the first phase of the proposed process, an in-depth qualitative analysis of official documents, media and social media contents, and interviews is conducted, in order to identify the basic beliefs, assumptions, rules and social expectations shaping the organisational field(s) in which the system under study is immersed. Coding is likely a very effective technique to group the detected beliefs, assumptions, rules and social expectations into consistent logics (Bryman \& Bell, 2011). The resulting list of institutional logics (with their respective attributes) can be validated, improved or updated through various techniques, such as experience surveys, focus groups, and questionnaires (Molina-Azorín \& López-Gamero, 2014).

In the second phase of the proposed process, the key resource stocks (and other DPM variables) for each institutional logic must be identified. Therefore, all the well-established indicators (KPIs) of the system under analysis can be reviewed and classified into the different institutional logics. Some indicators may correspond to variables that are relevant under more than one institutional logic: for example, a city's overall public transportation capacity is a relevant resource stock both under the environmental and the equality logic. The system dynamics approach underlying DPM provides a discipline to clearly distinguish the different types of variables: stocks, flows, performance drivers and inputs. In many cases, the existing and well-establish KPIs may not cover all of the variables that may be considered relevant under each logic. In this case, logic-specific expert surveys and focus groups may help complete the key stock mapping processes under each institutional logic. The output of this phase is a systematic list of key resource stocks under each institutional logic.

In the third phase of the proposed process, (potential) beneficiaries and contributors/exploiters of each resource stock identified in phase two are identified. These subjects, be they individual or collective, are the system's (potential) stakeholders, and actors. The recursive and collaborative process of DPM modelling cannot be successful if it does not consider these subjects. These subjects can be identified through qualitative research techniques, such as targeted interviews, and also computer-aided content analysis, based, for example, on social media contents. The output of this 
phase is a list of (potential) system actors under each institutional logic that is active in the relevant organisational field.

If DPM modellers follow the process synthesised in Figure 2, they will be able to develop, before the proper modelling phase, a systematic and inclusive list of key resource stocks (and relating flows) and key actors/stakeholder to be engaged (or taken into account) in the modelling process. The proposed process is designed to help the DPM modeller take into consideration all of the views that are active in society as for the system under study. If the modeller overlooks some institutional logics while developing the DPM model, the model may fail to take into consideration all of the key forces that are active at the system level; besides, the subjects backing the neglected logics are likely to delegitimate the model, independently from the model's potential for effective management.

In some cases, the models emerging from different logics can be integrated; in other cases, integration is too complex or frankly impossible, due to radical incompatibility between logics. In the latter cases, parallel modelling and model testing can be conducted, so that the decision of which model is better can emerge ex-post from data, rather than ex-ante from ideological biases.

\section{An illustrative pilot analysis: Institutional-logics-based DPM modelling of Universities' Third Mission Systems}

\section{Method}

The pilot analysis of universities' third mission viewed as a dynamic system illustrates the proposed process as synthesised in Figure 2. For the sake of concision, the study skips the analysis of organization-level variables (such as the university' liquidity), to allow the reader to focus on the innovative part of the analysis, that is, the analysis of those variables that, in the light of the active institutional logics, are relevant to the (re)generation of public value and the common good.

The DPM variables mapping universities' third mission systems have been identified through the in-depth qualitative analysis and coding of a set of representative documents on and around third mission (about 700 pages). Then, the resulting model has been discussed, integrated, fine-tuned and enriched with details through qualitative research (Luna-Reyes \& Andersen, 2003), by leveraging the results of 30 interviews to as many different people involved in the third mission activities of an important Italian university, which is considered as a national leader as for third mission engagement. The interviewees include people with several relevant roles in third mission activities from both within and outside the university's organisational boundaries. The interviews focus on discussing the model of the university's third mission as a dynamic system and eliciting ideas on how the model could be possibly improved. The results provide a fine-grained map of the key actors, resources, capabilities, constraints and behavioural triggers that can enable the third mission system to generate different forms of public value, or, on the contrary, hinder the system from those achievements.

\section{Results- Phase One: Identification of key institutional logics}

Our analyses suggest that several different institutional logics populate universities' third mission systems. Some of them are idiosyncratic to single or few universities, such as discipline-specific logics and the regional development logic of the area in which the university is embedded. We focused on the institutional logics that are quite generalizable as possibly present in all universities. By leveraging axial coding (Bryman \& Bell, 2011), we identified four third mission institutional logics, each including internally consistent groups of values, rules, and expectations. These four logics are listed below. 
1. Dissemination logic: The University is expected to spread well-established knowledge and best practices in the relevant communities and the larger public.

2. Engagement logic: The University is expected to directly flank and advice specific subjects (such as associations, government bodies, communities, firms) for pursuing specific common objectives.

3. Translational logic: The University is expected to translate the results of cutting-edge research into generalizable ready-to-use solutions (such as new procedures, new protocols, new software) that can be adopted by people, organisations, and communities even without the direct engagement of the University.

4. Entrepreneurial logic: The University is expected to contribute to the creation of new ventures and value propositions.

These four logics offer four radically different views on a university's third mission. In the light of each logic, the key common good to be (re)generated by the system is different. According to the dissemination logic, the third mission system is expected to generate resources such as free MOOCs, TV broadcastings, exhibits; according to the engagement logics, the third mission system is expected to generate resources such as the stock of businesses that have been flanked and/or advised by the University; according to the translational logics, the third mission system is expected to generate resources such as new health care protocols or new software solutions; according to the entrepreneurial logic, the third mission system is expected to generate resources such as patents or spin-offs.

Since these four logics focus on different variables and reflect possibly conflicting views on the university's role and mission, the DPM modeller can develop, at least in the first place, at least as many DPM models as the number of relevant logics identified. This allows the modellers to develop internally consistent models and avoid polarisation and conflict among the different groups, possibly cooperating to the DPM mapping and modelling work. Once the different models (one for each logic) are ready, they can be tested in parallel and also integrated, for example by analysing the effect of a variable that has been identified as key under a certain logic on other logic's models. For example, funding and incentives for entrepreneurial work can be introduced to improve the system under the entrepreneurial logic's standpoint, but what is the effect of these input variables in the system model developed, say, from the translational logic's standpoint? May the entrepreneurial-logic-based inputs backfire by discouraging too many faculties from engaging in translational activities? In other words, the preliminary differentiation in parallel modelling process enabled by institutional logic allows for successive, more comprehensive integration of the different views on the system under study.

Figure 3. Output example of Phase Two of institutional logic mapping: The stocks of key common resources to be (re)generated, according to the four different third mission logics identified in Phase 1. 


\begin{tabular}{|c|c|c|c|c|}
\hline $\mathrm{N}^{\circ}$ of active $[\ldots]$ & $\begin{array}{c}\text { [...] dissemination } \\
\text { products (publications, } \\
\text { exhibits, workshops, } \\
\text { MOOCs, } \\
\text { broadcasts, etc.) }\end{array}$ & $\begin{array}{l}{[\ldots] \text { engagement }} \\
\text { initiatives, where the } \\
\text { university supports } \\
\text { partners' pursue of } \\
\text { specific goals }\end{array}$ & $\begin{array}{l}{[\ldots] \text { translational }} \\
\text { products (protocols, } \\
\text { software, materials, } \\
\text { tools, etc.) and } \\
\text { relating publications }\end{array}$ & $\begin{array}{l}{[\ldots] \text { entrepreneurial }} \\
\text { products, including } \\
\text { service models and } \\
\quad \text { patents }\end{array}$ \\
\hline $\begin{array}{l}\mathrm{N}^{\circ} \text { of active } \\
\text { agreeements / } \\
\text { partnerships } \\
\text { envisaging }[\ldots]\end{array}$ & $\begin{array}{l}{[\ldots] \text { dissemination }} \\
\text { activities }\end{array}$ & $\begin{array}{l}{[\ldots] \text { engagement }} \\
\text { activities }\end{array}$ & $\begin{array}{l}{[\ldots] \text { translational }} \\
\text { activities }\end{array}$ & $\begin{array}{c}{[\ldots] \text { entrepreneurial }} \\
\text { activities (spin-offs, } \\
\text { incubated ventures, etc.) }\end{array}$ \\
\hline $\begin{array}{l}\mathrm{N}^{\circ} \text { of faculty who } \\
\text { contribute(d) to } \\
\text { active }[\ldots]\end{array}$ & $\begin{array}{l}{[\ldots] \text { dissemination }} \\
\text { products }\end{array}$ & $\begin{array}{l}{[\ldots] \text { engagement }} \\
\text { initiatives }\end{array}$ & $\begin{array}{l}{[\ldots] \text { translational }} \\
\text { projects and (or) } \\
\text { products }\end{array}$ & $\begin{array}{c}{[\ldots] \text { entrepreneurial }} \\
\text { initiatives }\end{array}$ \\
\hline $\begin{array}{c}\mathrm{N}^{\circ} \text { of active } \\
\text { competitive projects } \\
\text { and grants }[\ldots]\end{array}$ & $\begin{array}{l}{[\ldots] \text { including relevant }} \\
\text { dissemination products }\end{array}$ & $\begin{array}{l}{[\ldots] \text { including relevant }} \\
\text { engagement initiatives }\end{array}$ & $\begin{array}{l}{[\ldots] \text { including relevant }} \\
\text { translational initiatives }\end{array}$ & $\begin{array}{l}{[\ldots] \text { including relevant }} \\
\text { entrepreneurial } \\
\text { initiatives }\end{array}$ \\
\hline $\begin{array}{c}\mathrm{N}^{\circ} \text { of people } \\
\text { who }[\ldots]\end{array}$ & $\begin{array}{l}{[\ldots] \text { have used active }} \\
\text { dissemination products }\end{array}$ & $\begin{array}{l}{[\ldots] \text { have been flanked }} \\
\text { and (or) advised } \\
\text { through active } \\
\text { engagement initiatives }\end{array}$ & $\begin{array}{c}{[\ldots] \text { (could) benefit }} \\
\text { from the active } \\
\text { projects of translational } \\
\text { research and activities }\end{array}$ & $\begin{array}{l}{[\ldots] \text { are employed in }} \\
\text { spin-offs, incubated } \\
\text { ventures, and patent- } \\
\text { related activities }\end{array}$ \\
\hline $\begin{array}{c}\mathrm{N}^{\circ} \text { of businesses } \\
\text { or institutions } \\
\text { that }[\ldots]\end{array}$ & $\begin{array}{c}{[\ldots] \text { have used }} \\
\text { active dissemination } \\
\text { products }\end{array}$ & $\begin{array}{l}{[\ldots] \text { have been flanked }} \\
\text { and (or) advised } \\
\text { through active } \\
\text { engagement initiatives }\end{array}$ & $\begin{array}{c}{[\ldots] \text { (could) benefit }} \\
\text { from the active } \\
\text { projects of translational } \\
\text { research and activities }\end{array}$ & $\begin{array}{l}{[\ldots] \text { actively use }} \\
\text { patents }\end{array}$ \\
\hline $\begin{array}{l}\mathrm{N}^{\circ} \text { of scientific } \\
\text { publications } \\
\text { reporting on the } \\
\text { university's }\lceil\ldots\rceil\end{array}$ & $\begin{array}{l}{[\ldots] \text { dissemination }} \\
\text { activities }\end{array}$ & $\begin{array}{l}{[\ldots] \text { engagement }} \\
\text { activities }\end{array}$ & $\begin{array}{l}{[\ldots] \text { translational }} \\
\text { activities }\end{array}$ & $\begin{array}{l}{[\ldots] \text { entrepreneurial }} \\
\text { activities (spin-offs } \\
\text { and incubated } \\
\text { ventures, etc.) }\end{array}$ \\
\hline $\begin{array}{l}\mathrm{N}^{\circ} \text { of media } \\
\text { mentions and } \\
\text { public discussion } \\
\text { around }\lceil\ldots\rceil\end{array}$ & $\begin{array}{c}{[\ldots] \text { active dissemination }} \\
\text { products }\end{array}$ & $\begin{array}{c}{[\ldots] \text { active engagement }} \\
\text { initiatives }\end{array}$ & $\begin{array}{l}{[\ldots] \text { active projects, }} \\
\text { of translational } \\
\text { research and activities }\end{array}$ & $\begin{array}{l}{[\ldots] \text { active projects, }} \\
\text { patents, spin-offs, and } \\
\text { incubated ventures }\end{array}$ \\
\hline $\begin{array}{c}\mathrm{N}^{\circ} \text { of usable } \\
\text { feedbacks on }[\ldots]\end{array}$ & $\begin{array}{c}{[\ldots] \text { active }} \\
\text { dissemination } \\
\text { products }\end{array}$ & $\begin{array}{c}{[\ldots] \text { active engagement }} \\
\text { initiatives }\end{array}$ & $\begin{array}{c}{[\ldots] \text { active projects, of }} \\
\text { translational research } \\
\text { and activities }\end{array}$ & $\begin{array}{l}{[\ldots] \text { active projects, }} \\
\text { patents, spin-offs, and } \\
\text { incubated ventures }\end{array}$ \\
\hline $\begin{array}{c}{[\ldots] \text { that according }} \\
\text { to feedbacks, (may) } \\
\text { significantly } \\
\text { contribute to one or } \\
\text { more SDGs* }\end{array}$ & $\begin{array}{c}\mathrm{N}^{\circ} \text { of active } \\
\text { dissemination } \\
\text { products }[. . .]\end{array}$ & $\begin{array}{c}\mathrm{N}^{\circ} \text { of active } \\
\text { engagement } \\
\text { initiatives }[\ldots]\end{array}$ & $\begin{array}{l}\mathrm{N}^{\circ} \text { of active } \\
\text { translational } \\
\text { projects }[\ldots]\end{array}$ & $\begin{array}{c}\mathrm{N}^{\circ} \text { of active service } \\
\text { models, patents, spin- } \\
\text { offs, and incubated } \\
\text { ventures }[\ldots]\end{array}$ \\
\hline $\begin{array}{l}\text { *Specific measurem } \\
\text { (1) No Poverty; (2) Z } \\
\text { and Sanitation; (7) } \\
\text { Infrastructure; (10) } \\
\text { Production; (13) Cli } \\
\text { (17) Partnerships to }\end{array}$ & $\begin{array}{l}\text { ace Inequality; (11) } \\
\text { ate Action; (14) Life Be the Goals. }\end{array}$ & $\begin{array}{l}\text { and Well-being; (4) Qu } \\
\text { y; (8) Decent Work an } \\
\text { ustainable Cities and } \\
\text { w Water; (15) Life on }\end{array}$ & $\begin{array}{l}\text { ent Goal (SDG) identifie } \\
\text { y Education; (5) Gender } \\
\text { Economic Growth; (9) } \\
\text { mmunities; (12) Respo } \\
\text { and; (16) Peace and Ju }\end{array}$ & $\begin{array}{l}\text { by the United Nations: } \\
\text { quality; (6) Clean Water } \\
\text { idustry, Innovation and } \\
\text { sible Consumption and } \\
\text { tice Strong Institutions; }\end{array}$ \\
\hline
\end{tabular}

Source: authors own elaboration.

Results-Phase Two: Identification of the key resource stocks under each institutional logic 
Through collaborative data coding and discussion with our interviewees, we developed the lists of the key common resources to be re-generated according to the four different logics identified above. The results are synthesised in Figure 3.

The resource mapping displayed in Figure 3 shows that the suggested approach based on institutional logics allows the development of an orderly, systematic identification of key resource stocks. Thanks to the systematic, comparative analysis across all institutional logics, it is possible to create a logical framework that helps develop a set of variables/indicators that is well-balanced across logics. A systematic analysis of the main European indicator sets for university performance reveals that while some resources, included in Figure 2, are present in some or many indicator sets, others are often or always missing. For example, the "number of patents", a resource stock which is very important under the entrepreneurial logic, is present in many official indicator sets, while the "number of ready-to-use protocols", a resource stock that has similar importance under the translational logic, is almost always absent. Therefore, the logic-based mapping of key resource stocks may be a very useful process for overcoming the modellers' biases and systematically identifying of all the relevant variables/indicators, including those that are not displayed in mainstream indicator lists.

Table 1. Example of a working table for the identification of the actors involved around the dissemination logic of universities' third mission.

\begin{tabular}{|c|c|c|c|}
\hline & ACTORS & $\begin{array}{l}\text { (Possibly) benefitting } \\
\text { from the third } \\
\text { mission system } \\
\text { through (examples) }\end{array}$ & $\begin{array}{l}\text { (Possibly) contributing to } \\
\text { key resources through } \\
\text { (examples of resources, } \\
\text { performance drivers and } \\
\text { inputs) }\end{array}$ \\
\hline \multirow{14}{*}{$\begin{array}{l}\text { Dissemination } \\
\text { logic }\end{array}$} & Core University & Reputation... & $\begin{array}{l}\text { Technical support ratio } \\
\text { (e.g. media production)... }\end{array}$ \\
\hline & Departments A, B, C.. & Funding... & Internal incentives... \\
\hline & Faculty & Fame... & Faculty engagement ratio... \\
\hline & Businesses & Innovation stimuli.. & Feedback... \\
\hline & City / Region & Attractiveness... & Infrastructural capability... \\
\hline & Social movements & Legitimation... & Legitimation... \\
\hline & University Partners A, B, C... & Legitimation... & Externalised work... \\
\hline & Other educational institutions & Orientation... & $\ldots$ \\
\hline & $\begin{array}{l}\text { Other institutions (museums, } \\
\text { trade associations...) }\end{array}$ & $\begin{array}{l}\text { Enlarged value } \\
\text { proposition... }\end{array}$ & $\cdots$ \\
\hline & Communities & Cohesion, stimuli.. & \\
\hline & National Government/Ministry & $\ldots$ & $\ldots$ \\
\hline & Citizens & $\ldots$ & $\ldots$ \\
\hline & Next generation's advocates & $\ldots$ & $\ldots$ \\
\hline & 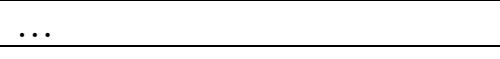 & & \\
\hline
\end{tabular}

Source: authors own elaboration.

\section{Results - Phase Three: identification of the key actors according to each institutional logic}

In the third step of the institutional-logics-based approach to DPM proposed above, all the actors that (may) benefit from common resources and contribute to common flows by influencing inputs and common performance drivers are identified. Through collaborative data coding and discussion with our interviewees, we developed the lists of (possible) benefitting and contributing actors. The results confirmed that the lists of relevant actors developed based on the four different institutional logics partially differ from each other, thus suggesting that the institutional-logics-based approach to 
DPM proposed above is actually useful to achieve a more inclusive and systematic mapping of the (potential) stakeholders. The process of identifying the key (potential) actors, the (potential) benefits they enjoy from the system, and their (possible) contribution can be carried on based on a working table like that shown in Table 1.

Once filled in, tables like those presented in Table 1 provide a useful basis for DPM modelling. In fact, the "benefitting from" column lists some resource stocks that are indirectly key to system functioning: for example, under the dissemination logic, the system needs to keep providing the university departments with funding stemming from dissemination activities, in order to give the departments good reasons to develop/keep sufficient internal incentives for faculties performing dissemination activities.

\section{Results - Starting the institutional logics-based DPM modelling process}

In this paragraph, we will give a synthetic illustrative example of how the results of Phases 1, 2 and 3 of the process synthesized in Figure 2 can be leveraged to develop a DPM modelling process that is more systematic, unbiased, inclusive and effective than the process that can be developed based on already-existing indicators and/or traditional stakeholder engagement processes only. Figure 4 illustrates the contents of this paragraph.

Phase 1 results in the identification of the institutional logics that are relevant to the system under study. In the exemplary case presented here, four institutional logics of a university's third mission are identified (dissemination, engagement, translational, and entrepreneurial). Further "sister logics" may be identified that influence the system as well, such as the inclusion logic of teaching (based on including as many disadvantaged students as possible to university education) or the excellence logic of research (based on publish-or-perish on top journals). Thanks to Phase 1 results, the modeller can develop as many models as the different logics that are identified as relevant, for a preliminary parallel analysis (see Figure 4).

Phase 2 results in the identification of the key resource stocks from the standpoint of each institutional logic, like those listed in Figure 3. These results can be used to fill in the "Resources" and "Results" sections of the DPM diagram, like in Figure 4.

Phase 3 results in the identification of the resources (potentially) benefitting the (potential) contributors (of the system), as in Table 1. These can be considered key resources, to the extent they provide essential incentive/reason for contributing to the system. Also, in phase 3, some key capabilities of (potential) contributors are identified, that can be included in the DPM diagram as performance drivers. Finally, also some key inputs influencing actors are identified in Phase 3 (see Table 1), that can be included in the DPM diagram.

Figure 4 provides an illustrative example (that is necessarily far from being exhaustive, due to space constraints) of the rich variable mapping results emerging from the institutional logics - based approach proposed by this study.

Figure 4. How the results of Phases 1, 2 and 3 of the Preliminary Logic Mapping process can help conduct effective DPM modelling: an example of ongoing identification of DPM variables based on the Preliminary Logic Mapping of universities' third mission. 


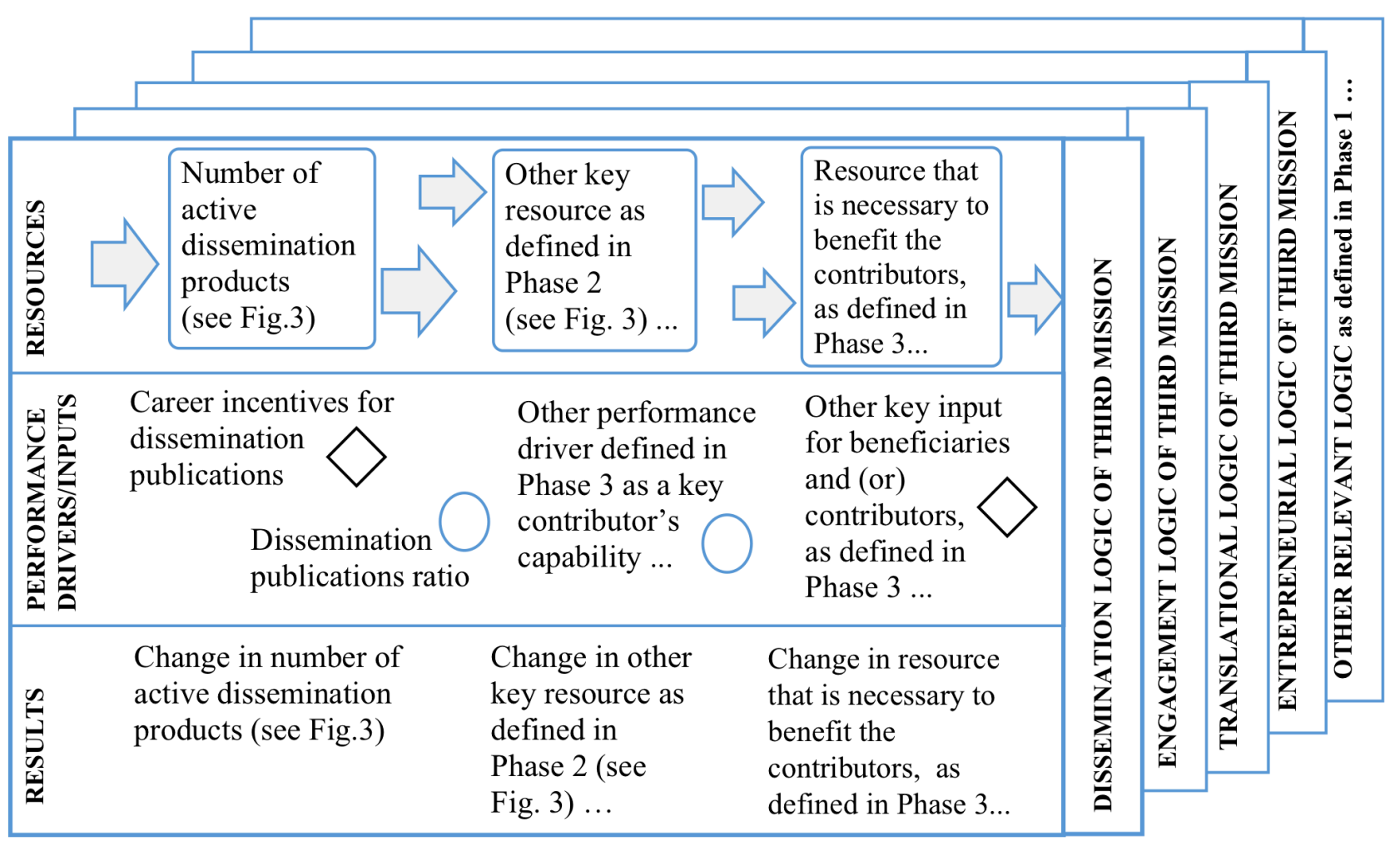

Source: authors own elaboration.

\section{Conclusions}

The institutional logics view has proved particularly useful to map the common good variables under the different points of view that shape the organisational field. This significantly helps overcome the excessive focalization on the sole logic of economic sustainability, that typically governs choices at the organisational level, and take into consideration all the different sets of social expectations around the possible societal level impacts of the eco-socio-technical system under study.

Even if governance and strategy are based on the prioritisation of some logics over others (for example, a specific University may decide to prioritise the dissemination logic over, say, the entrepreneurial logic), the different logics continue to exist at the societal level and dynamically influence the system. For this reason, it is particularly important to map all of the DPM variables under all of the key institutional logics that are active in the system under study. Otherwise, the DPM analysis is likely to miss some key aspects of the dynamics that (may) generate public value.

The pilot study conducted on universities' third mission systems suggests that conducting a preliminary, in-depth analysis of the relevant institutional logics is important also because this gives the impression to all the people who collaborate to modelling that all the points of view are being taken into consideration and that the choice of indicators will be neutral and inclusive, rather than ideologically oriented and exclusive. This inclusiveness and neutrality proved very important to discourage counter-productive polarisation into opposing coalitions in the phase of variable identification.

In this light, the pilot analysis conducted by this study suggests that the focal organization/institution that is at the core of the system under study (in this case, the university that is at the core of a third mission system) should play a pivotal role as an engine of dynamic integration and reconciliation within and across all of the relevant logics, in order to effectively manage the intertwining fragilities of the key common resources that the system is expected to (re)generate. 


\section{Reference List}

Ansari, S., Wijen, F., \& Gray, B. (2013). Constructing a climate change logic: An institutional perspective on the "tragedy of the commons". Organization Science, 24(4), 1014-1040.

Ansell, C. (2011). Pragmatist democracy: Evolutionary learning as public philosophy. New York: Oxford University Press.

Ansell, C., \& Gash, A. (2008). Collaborative governance in theory and practice. Journal of Public Administration Research and Theory, 18, 543-571.

Beckert, J. (2010). How do fields change? the interrelations of institutions, networks, and cognition in the dynamics of markets. Organization Studies, 31(5), 605-627.

Bianchi, C. (2015). Enhancing joined-up government and outcome-based performance management through system dynamics modeling to deal with wicked problems: The case of societal ageing. Systems Research \& Behavioural Science, 32(4), 502-505.

Bianchi, C. (2016). Dynamic Performance Management. Berlin: Springer International Publishing.

Bianchi, C., Bovaird, T., \& Loeffler, E. (2017). Applying a Dynamic Performance Management Framework to Wicked Issues: How Coproduction Helps to Transform Young People's Services in Surrey County Council, UK. International Journal of Public Administration, 40(10), 833846.

Borgonovi, E., Bianchi, C., \& Rivenbark, W. C. (2017). Pursuing Community Resilience through Outcome-Based Public Policies: Challenges and Opportunities for the Design of Performance Management Systems. Public Organization Review, 19(2), 153-158.

Borgonovi, E., Anessi Pessina, E., \& Bianchi, C. (Eds.). (2018). Outcome-Based Performance Management in the Public Sector. Cham: Springer.

Bryman, A., \& Bell, E. (2011). Business research methods. Oxford: Oxford University Press.

Cantino, V., Devalle, A., Cortese, D., Ricciardi, F., \& Longo, M. (2017). Place-based network organizations and embedded entrepreneurial learning: emerging paths to sustainability. International Journal of Entrepreneurial Behavior and Research, 23(3), 504-523.

Cosenz, F. (2014). A Dynamic Viewpoint to Design Performance Management Systems in Academic Institutions: Theory and Practice. International Journal of Public Administration, 37(13), 955969.

Cosenz, F. (2018). Supporting public sector management through simulation-based methods: a dynamic performance management approach. International Review of Public Administration, 23(1), 20-36.

Dalpiaz, E., Rindova, V., \& Ravasi, D. (2016). Combining Logics to Transform Organizational Agency: Blending Industry and Art at Alessi. Administrative Science Quarterly, 61(3), 347-392.

De Bernardi, P., Azucar, D., Forliano, C., Bertello, A. (2020). Innovation and Entrepreneurial Ecosystems: Structure, Boundaries, and Dynamics. In De Bernardi, P. \& Azucar, D. (Eds.) Innovation in Food Ecosystems. Contributions to Management Science. Cham: Springer, pp. 73104.

De Bernardi, P., Bertello, A., \& Shams, S. M. (2019). Logics Hindering digital transformation in cultural heritage strategic management: An exploratory case study. Tourism Analysis, 24(3), 315-327. 
De Bernardi, P., Bertello, A., Forliano, C. (2019). Unpacking Higher Educational Institutions (HEIs) performances through the institutional logics lens. In Proceedings of the 14th International Forum on Knowledge Asset Dynamics, pp. 1537-1555.

Deber, R., \& Schwartz, R. (2016). What's measured is not necessarily what matters: A cautionary story from public health. Healthcare Policy, 12(2), 52-64.

Dover, G. J. (2010). Public sector volunteering: Committed staff, multiple logics, and contradictory strategies. Review of Public Personnel Administration, 30(2), 235-256.

El-Jardali, F., Ataya, N., \& Fadlallah, R. (2018). Changing roles of universities in the era of SDGs: Rising up to the global challenge through institutionalising partnerships with governments and communities. Health Research Policy and Systems, 16(1), 1-5.

Eversole, R. (2011). Community Agency and Community Engagement: re-theorising Participation in Governance. Journal of Public Policy, 31(1), 51-71.

Fairclough, S., \& Micelotta, E. R. (2013). Beyond the family firm: Reasserting the influence of the family institutional logic across organizations. In Lounsbury, M. \& Boxenbaum, E. (Eds.) Institutional Logics in Action, Part B (Research in the Sociology of Organizations, Vol. 39 Part B). Bingley: Emerald Group Publishing Limited, pp. 63-98.

Fuster, E., Padilla-Meléndez, A. Lockett, N., \& Del-Águila-Obra, A. R. (2019). The emerging role of university spin-off companies in developing regional entrepreneurial university ecosystems: The case of Andalusia. Technological Forecasting and Social Change, 141(C), 219-231.

Garcia-Perez-de-Lema, D., Madrid-Guijarro, A., \& Martin, D. P. (2017). Influence of universityfirm governance on SMEs innovation and performance levels. Technological Forecasting and Social Change, 123, 250-261.

Greenwood, R., Díaz, A. M., Li, S. X., \& Lorente, J. C. (2010). The multiplicity of institutional logics and the heterogeneity of organizational responses. Organization Science, 21(2), 521-539.

Greenwood, R., Hinings, C. R., \& Whetten, D. (2014). Rethinking institutions and organizations. Journal of Management Studies, 51(7), 1206-1220.

Gür, U., Oylumlu, İ. S., \& Kunday, Ö. (2017). Critical assessment of entrepreneurial and innovative universities index of Turkey: Future directions. Technological Forecasting and Social Change, 123(C), 161-168.

Kapetaniou, C., \& Lee, S. H. (2017). A framework for assessing the performance of universities: The case of Cyprus. Technological Forecasting and Social Change, 123, 169-180.

Luna-Reyes, L. F., \& Gil-Garcia, J. R. (2011). Using institutional theory and dynamic simulation to understand complex e-Government phenomena. Government Information Quarterly, 28(3), $329-345$.

Luna-Reyes, L. F., \& Andersen, D. L. (2003). Collecting and analyzing qualitative data for system dynamics: methods and models. System Dynamics Review, 19(4), 271-296.

Macy, M. W., \& Willer, R. (2002). From factors to actors: Computational sociology and agent-based modeling. Annual Review of Sociology, (28)1, 143-166.

Mejlgaard, N., \& Ryan, T. K. (2017). Patterns of third mission engagement among scientists and engineers. Research Evaluation, 26(4), 326-336.

Molina-Azorín, J. F., \& López-Gamero, M. D. (2014). Mixed Methods Studies in Environmental Management Research: Prevalence, Purposes and Designs. Business Strategy and the 
Environment, 25(2), 134-148.

Montesinos, P., Carot, J. M., Martinez, J. M., \& Mora, F. (2008). Third mission ranking for world class universities: Beyond teaching and research. Higher Education in Europe, 33(2-3), 259271.

Moynihan, D. P. (2008). The dynamics of performance management. Washington DC: Georgetown University Press.

Negoita, M. (2018). Beyond Performance Management: A Networked Production Model of Public Service Delivery. Public Performance and Management Review, 41(2), 253-276.

Noto, G., \& Noto, L. (2018). Local Strategic Planning and Stakeholder Analysis: Suggesting a Dynamic Performance Management Approach. Public Organization Review.

Pierce, P., Ricciardi, F., \& Zardini, A. (2017). Smart Cities as Organizational Fields : A Framework for Mapping Sustainability-Enabling Configurations. Sustainability, 9(9), 1-21.

Raafat, Z., Hoffman, A., Saeed, K., Tichenor, K., Radzicki, M., \& Pavlov, O. (2013). Strategies for University Growth. A System Dynamics Analysis of Organizational Change. In The 2013 System Dynamics Conference, pp. 1-7.

Rossignoli, C., Ricciardi, F., \& Bonomi, S. (2018). Organizing for Commons-Enabling DecisionMaking Under Conflicting Institutional Logics in Social Entrepreneurship. Group Decision and Negotiation, 27, 417-443.

Sánchez-Barrioluengo, M., \& Benneworth, P. (2019). Is the entrepreneurial university also regionally engaged? Analysing the influence of university's structural configuration on third mission performance. Technological Forecasting and Social Change, 141, 206-218.

Sauermann, H., \& Stephan, P. (2013). Conflicting logics? a multidimensional view of industrial and academic science. Organization Science, 24(3), 889-909.

Saz-Carranza, A., \& Longo, F. (2012). Managing competing institutional logics in public-private joint ventures. Public Management Review, 14(3), 331-357.

Secundo, G., Elena Perez, S., Martinaitis, Ž., \& Leitner, K. H. (2017). An Intellectual Capital framework to measure universities' third mission activities. Technological Forecasting and Social Change, 123, 229-239.

Skribans, V., Lektauers, A., \& Merkuryev, Y. (2013). Third Generation University Strategic Planning Model Development, paper presented at. In Proceedings of the 31th International Conference of the System Dynamics Society, pp. 1-7.

Sorci, P. (2017). Governing Local Area Development through Dynamic Performance Management: Towards an Inter-Institutional Outcome-Based Perspective. Public Organization Review.

Sterman, J. (2000). Business dynamics. Systems Thinking and modeling for a complex world. Boston: Irwin/McGraw Hill.

Thornton, P. H., Ocasio, W., \& Lounsbury, M. (2012). The institutional logics perspective: foundations, research, and theoretical elaboration. Oxford: Oxford University Press.

Tracey, P., Phillips, N., \& Jarvis, O. (2011). Bridging institutional entrepreneurship and the creation of new organizational forms: A multilevel model. Organization Science, 22(1), 60-80.

Wahid, F., \& Sein, M. K. (2013). Institutional entrepreneurs: The driving force in institutionalization of public systems in developing countries. Transforming Government: People, Process and 
Policy, 7(1), 76-92.

Wooten, M., \& Hoffman, A. J. (2008). Organizational Fields: Past, Present, and Future. In R. Greenwood, C. Oliver, R. Suddaby, \& K. Sahlin (Eds.), Handbook of Organizational Institutionalism (pp. 130-147). Sage Publications.

Zietsma, C., \& Lawrence, T. B. (2010). Institutional work in the transformation of an organizational field: The interplay of boundary work and practice work. Administrative Science Quarterly, $55(2), 189-221$.

\begin{abstract}
About the authors
Francesca Ricciardi is Associate Professor of Business Organization at the University of Turin, Department of Management, and Visiting Lecturer in "Organizations and Communities" at the University of Lund, Sweden. She is a co-founder of the Smart Commons Lab, a non-profit association dedicated to the development of innovative management models for the common good. Previously, she has held research and teaching positions at the University of Verona, the University of Genoa and the Catholic University of Brescia. Her research interests include inter-organizational networks and relationships; IT management, digital transformation and innovation ecosystems; and new organizational forms for sustainability, commons development, and the knowledge economy. Before dedicating herself entirely to research and teaching activities, she worked as a consultant in the areas of facility management and then executive search.
\end{abstract}

Paola De Bernardi is Assistant Professor of Management Control Systems at the Department of Management, University of Turin, Italy. Her research and teaching alike focus on performance measurement and control systems, digitization and sustainable business model innovation, integrated thinking, and triple-bottom-line sustainability. She is a member of the Accademia Italiana di Economia Aziendale (AIDEA/SIDREA), serves as the coordinator of EIT Food educational programs for the University of Turin, and is a founding member of the Smart Commons Lab - an international network of business professionals and organizations with the shared mission of creating and disseminating new generations of dynamic tools for the innovative management of common resources and public value.

Canio Forliano is a Ph.D. Student in System Dynamics at the University of Palermo, Department of Political Science and International Relations. He is also working as a Research and Teaching Assistant at the Department of Management at the University of Turin, where he has been involved in two Industry 4.0 research projects involving local manufacturing and food companies. He is part of the SIDREA national research group regarding public universities' governance and the evaluation of their performances. His research interests cover the following topics: system dynamics, entrepreneurial universities and third mission, and business model innovation.

Mattia Franco is a Research and Teaching Assistant of Management Control Systems at the University of Turin, Department of Management. He has a Master's degree in Business Administration, and his research topics are climate change risk and opportunities disclosure, integrated thinking, and sustainability reporting. He is also working on an Industry 4.0 research project. 